\title{
Implementation of a standard work routine using Lean Manufacturing tools: A case Study
}

\author{
Implantação de uma rotina padrão de trabalho utilizando as \\ ferramentas da Manufatura Enxuta: Estudo de Caso
}

\author{
Diego Michael Cornelius dos Santos ${ }^{1 *}$ (D), Bruna Karine dos Santos ${ }^{2}$ (D), \\ César Gabriel dos Santos ${ }^{3}$
}
${ }^{1}$ Universidade Federal de Santa Maria - Mestrando em Engenharia Mecânica. Avenida Roraima, 1000, Santa Maria - RS Brasil, CEP: 97105-900. E-mail: diego.mdossantos@hotmail.com
2Universidade Federal de Santa Maria - Mestranda em Engenharia Agrícola. Avenida Roraima, 1000, Santa Maria - RS Brasil, CEP: 97105-900. E-mail: bksantos09@gmail.com
${ }^{3}$ Universidade Federal de Santa Maria - Departamento de Engenharia Mecânica, Centro de Tecnologia - CT. Avenida Roraima, 1000, Santa Maria - RS Brasil, CEP: 97105-900. E-mail: cesar.g.santos@ufsm.br

How to cite: Santos, D. M. C., Santos, B. K., \& Santos, C. G. (2021). Implementation of a standard work routine using Lean Manufacturing tools: A case Study. Gestão \& Produção, 28(1), e4823. https://doi.org/10.1590/0104-530X4823-20.

\begin{abstract}
Due to technological advances, trade politicies and society's consumption patterns, competitiveness among companies has increased considerably, requiring practices that provide a constant improvement in production indicators and product quality. In this context, the use of Toyota Production System tools, also known as Lean Manufacturing, have a fundamental role in the elimination of waste and continuous improvement of industrial production levels. Thus, this work aims to implement a standardized work routine among employees working in a market of parts in an Agricultural Machinery industry, which lacks production methods. To represent this situation, real data were used, which correspond to the needs of the assembly line, and which served as the basis for the analysis and implementation of a new work routine. The results obtained enabled the creation of a standardized work routine, which was obtained by balancing activities between operators and eliminating activities that did not add value to the product.
\end{abstract}

Keywords: Takt time; Standardized work; Productivity; Lean manufacturing; Yamazumi board.

Resumo: Devido aos avanços tecnológicos, políticas de comércio e padrões de consumo da sociedade, a competitividade entre as empresas vem aumentando consideravelmente, exigindo práticas que proporcionem uma melhoria constante nos indicadores de produção e na qualidade dos produtos. Neste contexto, a utilização das ferramentas do Sistema Toyota de Produção, também conhecido como Lean Manufacturing, possuem papel fundamental para a eliminação de desperdícios e melhoria continua dos níveis de produção industrial. Desta maneira, este trabalho tem como objetivo implementar uma rotina padronizada de trabalho entre os colaboradores que atuam em um mercado de peças de uma indústria de Máquinas Agrícolas, a qual carece de métodos produtivos. Para representar esta situação, foram utilizados dados reais, os quais correspondem a necessidade da linha de produção, e que serviram de base para a análise e implementação de uma nova rotina de trabalho. Os resultados obtidos possibilitaram a criação de uma rotina de trabalho padronizada, a qual foi obtida através do balanceamento das atividades entre os operadores e eliminação de atividades que não agregavam valor ao produto.

Palavras-chave: Takt time; Trabalho padronizado; Produtividade; Lean manufacturing; Yamazumi board.

Received May 08, 2018 - Accepted Nov. 14, 2019

Financial support: none. 


\section{Introduction}

With the growing competitiveness among organizations because of technological advancements, trade policies and consumption patterns, the employment of practices that enable the continuous improvement of production indicators becomes a differential for organizations. However, many companies end up not having an adequate control of the activities performed during their production process. In this scenario, organizations searching for a differential in face of their competitors are constantly focused in reducing costs, improving their products' quality whilst increasing their productivity with focus on meeting their clients' needs.

Lean Manufacturing system, also known as Toyota Production System, positively revolutionized automobile industry in Japan during the 1950's. The practices defended by Toyota System Production have been adopted by the most varied industrial branches around the world. This Production System is based on the elimination of waste to improve production levels in companies. To enable the elimination of waste, specific tools are used in order to manage processes and other activities performed inside the company (Liker \& Meier, 2007).

In this context, this article aims at implementing a standard work routine through the use of Lean Manufacturing tools, searching to optimize the distribution of activities among operators in the Logistics Sector of an agricultural machinery manufacturing company.

\section{Literature review}

The literature review approaches concepts and theories relating to the company's goals. Fundamental concepts such as Lean Manufacturing, Takt Time, Value Stream Mapping, and Standardized Work. These are fundamental concepts to apply Lean Manufacturing methodology in an industrial environment.

\subsection{Lean manufacturing}

In the aftermath of World War II, Japan found itself with scarce resources, domestic market was limited and the country's economy was ruined, detaining the manufacture based on elevated productive levels (Womack et al., 1992). Toyota Production System (TPS), in this sense, arose form the need to produce a large range of product models but in a reduced quantity (Collatto et al., 2016).

Aiming to enhance industrial manufacture levels, Lean Manufacturing focus on eliminating eight kinds of waste that do not add value to the production process and that must be avoided throughout the development of products in a lean process: i) Overproduction; ii) Time on hand; iii) Transportation; iv) Processing itself; v) Excess inventory; vi) Unnecessary movement; vii) Defective products; viii) Underutilization of workers' creativity. For these wastes to be eliminated or considerably reduced, Lean Manufacturing provides several tools that enable the management and the visualization of the processes and the activities, such as: $5 \mathrm{~s}$, Poka-yoke, Kanban, Operator Balance Chart, Value Stream Mapping, Standardized Work, among others (Liker \& Meier, 2007)

The implementation of Lean Manufacturing System allows for a process to be carried out using fewer materials and demanding fewer investments. This enables a decrease in the inventory levels by consuming less space and with the use of fewer human resources. Thus, in this production system, workflow becomes more 
predictable, reducing levels of uncertainty and disorder, establishing trust, convenience, and tranquility for all parties involved in the process (Wilson, 2010).

By implementing the concepts of lean manufacturing, it is possible to reduce the cycle duration of internal industrial processes through shifts in work methods. With this, deliveries are done according to deadlines defined, enhancing the components' quality and increasing trust in the supplier-client relationship, with the former being seen as partners (Bartz et al., 2013).

Lean Manufacturing has as a main feature the elimination of waste. This consequently leads to reducing costs, allowing the company to improve assessment methods that may result in monetary gains with its implementation in different areas of the company (Walter \& Tubino, 2013).

Besides the enhancement in production, a lean manufacture enables to organize and manage relationships between clients and suppliers in an optimized manner, allowing a diversified production, with quality, and a low level of stocks faced with the fluctuations of market demand (Santos \& Alves, 2015).

\subsection{Takt time}

As cited by Iwayama (1997), Takt Time is about the time calculated for the production of a part or a whole product. It can be applied for a work cell or even for an assembly line. Therefore, Takt Time cannot be treated as absolute data, but it is determined based on the available work time and the units to be produced. It can be understood, following this, that Takt Time informs the time slots necessary to manufacture a product in each manufacture process. In other words, the time slot in which the product must be processed.

Takt Time may be defined based on the market demand and the time available for production, that is, it is about the pace of production necessary to answer the demand. It is the result of the ratio of work time available by slot and the number of units for production, as it can be seen in Equation 1 (Alvarez \& Antunes, 2001).

TAKT TIME $=\frac{\text { work time available by } \operatorname{shift}(\text { minutes })}{\text { units to be produced }(\text { machines })}$

If each process exceeds Takt time, the results are scarcity of products; but if it faster, there will be an oversupply. When Takt Time is correctly observed, both activities in the work stations flow in the same pace, only producing the number of parts that were demanded for (Imai, 2014).

\subsection{Operator Balance Chart (OBC)}

The production balance is one of the TPS pillars and its objective is to make the operators involved in an activity to produce only the cessary amount of work to maintain the pace of the assembly line, not causing delays in production. In other words, production processes must be organized so that only the necessary quantity in the necessary timing is produced (Shingo, 1996).

In this context, Operator Balance Chart, also known as Yamazumi Board, is a graphic tool that helps to create a continuous flow in a process with multiple stages and 
several operators, distributing activities among operators according to Takt Time. As it is illustrated in Figure 1, vertical bars are used to indicate the quantity of work that must be performed by each operator. Each bar is formed by small bars proportional to the time of each activity (Lean Enterprise Institute, 2003).
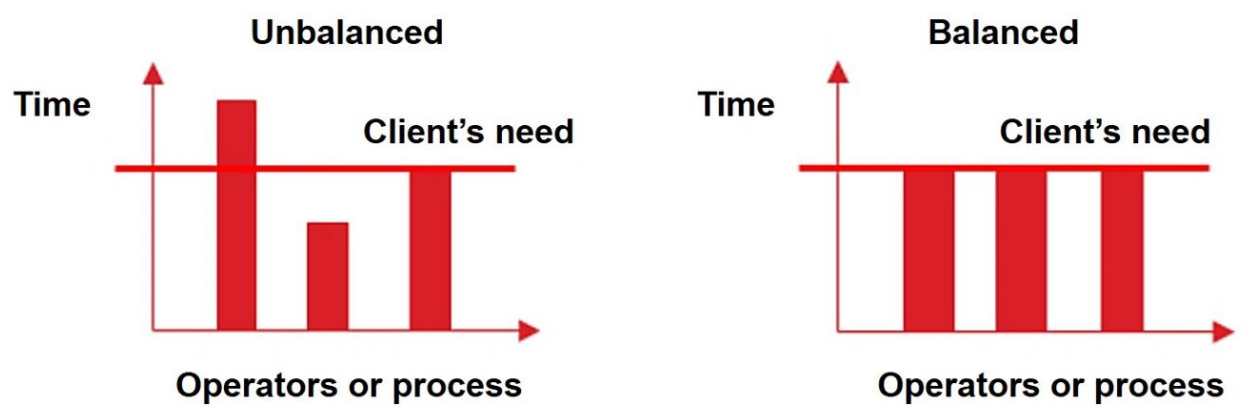

Figure 1. Model of Operator Balance Chart. Source: Adapted from Rother \& Shook, 2003.

According to Peinado \& Graeml (2007) and Slack et al. (2002), processes hardly present the same volume of work employed in each work station, that is, operations are not in perfect balance. This means that in a specific part of the production process, there will be a slower operation, and it will determine the production speed in all of the assembly line. This slower operation is called a bottleneck.

For Wilson (2010), the implementation of the Operator Balance Chart enables the visualization of important information on the analyzed process, such as:

- Waste of time: the vertical distance of the Takt Time line in relation to time cycle of the work station represents waiting time, that is, time wasted in this work station.

- Degree of balance reached: comparing the height of the bars, the balance/imbalance of the process may be observed and, later, the balance between operations can be enhanced through the task redistribution.

- Process bottleneck: in case the higher bar exceeds the Takt Time line, it is indicating which of the operators is under overload, causing delays and even stops in the process.

According to Sabadka et al. (2017), Yamazumi board consists of an ideal tool to enhance productivity in an industrial environment, because its implementation is able to significantly reduce the production time, enhancing the efficiency of the operator and enabling the balance among the assembly cells.

\section{Standardized work}

Standardized work establishes precise work procedures for each of the operators in a production process based on three elements: Takt Time, the work sequence, and the standard inventory (Lean Enterprise Institute, 2003).

The Work Standards Sheet contains work elements in sequence of operation, monitoring the length of each activity. As a reference, one has the Takt Time line which represents the limit time in which activities must be performed, as it can be seen in Figure 2. 


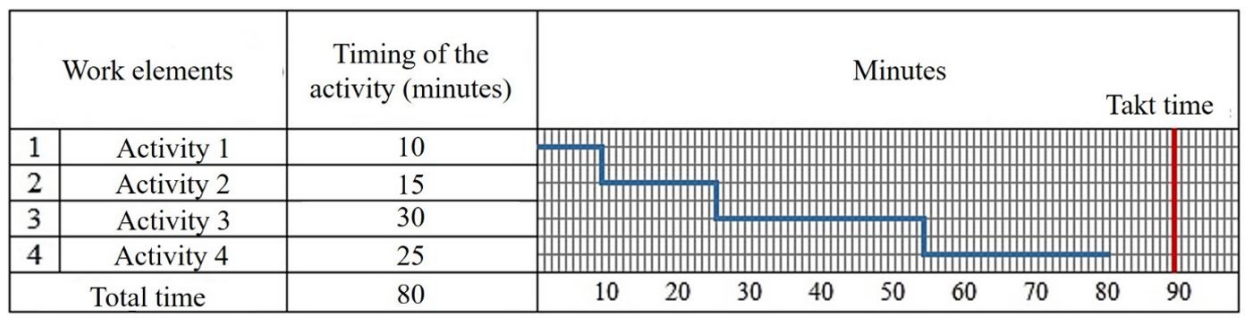

Figure 2. Model of Work Standards Sheet.

Source: Adapted from Lean Enterprise Institute (2003).

The work standards sheet is a tool for analysis that can be considered as set of instructions for the operator in which it is possible to analyze and understand losses in each operation. The use of this tool will provide information referring to the balanced workflow during the creation of a continuous flow. As a tool for analysis, Standardized Work will help employees identifying movements (walking, arriving) and waiting times (when the work cycle is below Takt Time) (Liker \& Meier, 2007).

In this context, Wilson (2010) adds that standardized work is a fundamental tool in the assessment and the assistance of the synchronized production process, used to review performance of the process, including its cycle time.

By means of implementing this tool, it is possible to distribute workloads in Takt Time, meeting the client's demand without the necessity of extra hours. If work elements of one or more operators exceed Takt Time, it is possible to transfer these elements for other operators, distributing activities in a balanced way. With the reduction of the workload following Takt Time, it is possible to eliminate idleness and waste in waiting time (Kishida et al., 2006).

\subsection{Value Stream Mapping (VSM)}

Movements by operators can be classified as operation and loss. The loss consists of any activity that does not contribute to the operations, such as waiting, accumulation of semi-processed parts, reloading etc. Operations can be divided in operations that do add value and the ones that do not. For example, among the ones that do not add value: walking, unnecessary movements with the material, unpacking parts coming from suppliers etc. As for the operations that add value, they really transform the raw material or service, modifying its form or quality (Shingo, 1996).

A value stream represents the necessary actions to locate a product in all essential streams for its complete manufacture, even if this action adds value or not to the final product. Therefore, value stream mapping helps in visualizing and understanding the stream of materials and information as the products follow their stream. In other words, in this stage, the production track of a specific product must be monitored from its beginning to the end, through a visual representation of each process in the stream of materials and information (Rother \& Shook, 2003).

Value Stream Mappings offer a simplified language of the whole process and enable understanding in a manner that allows every party involved to have the same shared view of wastes. The current Value Stream Mapping must show processes and the stream of material from one process to the other. It is possible, with it, to observe waste and possible areas that may be enhanced. In other words, the purpose of the current value stream mapping is to understand the nature of processes in a manner that allows for a future value stream mapping to be created (Liker \& Meier, 2007). 
Value Stream Mapping (VSM) is a technique originally developed by Toyota and later popularized in the book "Learning to See", written by Rother and Shook in 1998. VSM enables the visualization, analysis, reduction and complete elimination of waste. This tool, then, aims at enhancing processes, eliminating or reducing operations that do not add value to the final product (Wilson, 2010). For it to occur, the Value Stream Mapping illustrating the current situation must be carried out and, afterwards, a Future Value Stream Mapping can be made, as it is illustrated in Figure 3.

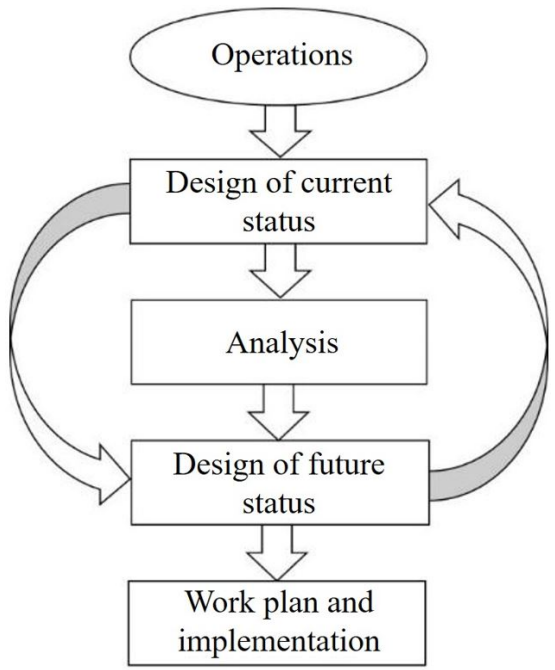

Figure 3. Operation system of Value Stream Mapping. Source: Adapted from Rother \& Shook (2003).

Total Value Stream comprehends all sectors of the company, from negotiations with suppliers to the delivery of the product to clients. However, as it is illustrated in Figure 4, this article will approach the implementation of Lean Manufacture in the Logistics area, specifically focusing in a market of parts.

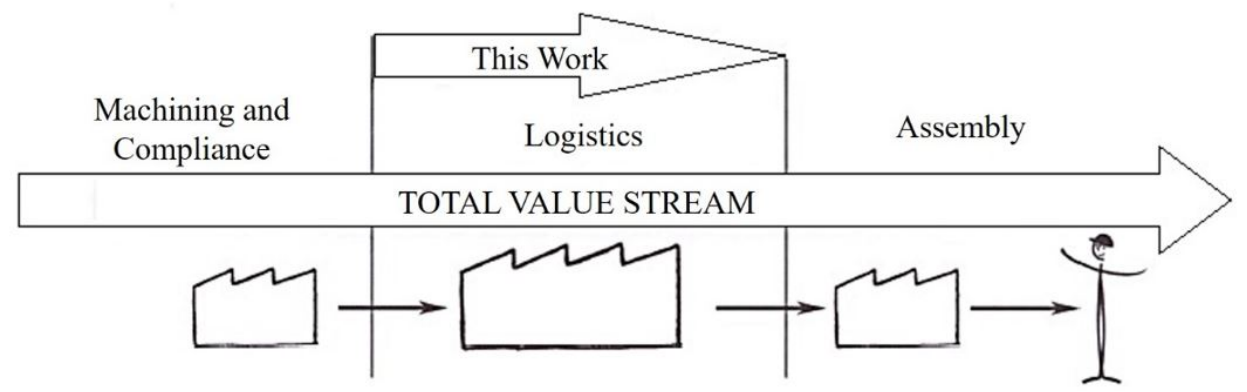

Figure 4. Site of VSM implementation. Source: Adapted from Rother \& Shook, (2003).

The implementation of the proposed model in the company's supply chain may result in the enhancement of performance indicators, even within a brief time since it begins. The proposed model maximizes advantages of the systems under study at the same time that it minimizes their limitations, resulting in the accomplishment of managers' needs in the search for success in their companies (Santos \& Alves, 2015). 


\section{METHODOLOGY}

The work was carried out in the logistics area of an agricultural machinery industry located in the northwestern region of the Rio Grande do Sul state. The logistical activities of this company are based on the input of material (Figure 5a) and the supply of parts to the assembly line via restocking boxes that are later returned empty from the assembly line (Figure 5b). After the boxes are loaded, stock routes are carried out in a way that answer the assembly line without causing any supply problems in workstations.

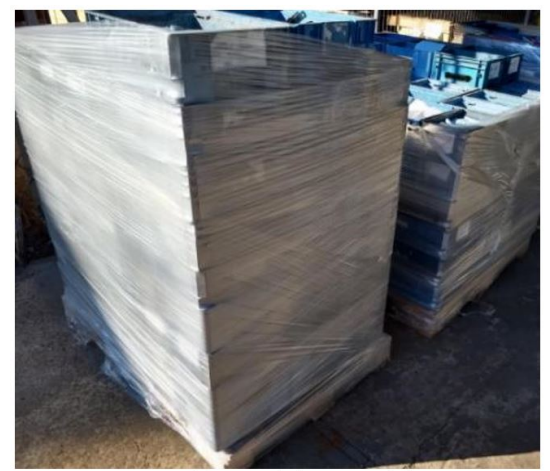

(a) Receiving material

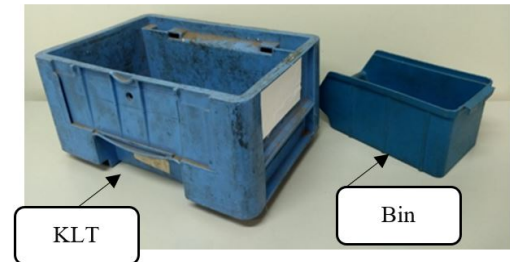

(b) Return of empty packages from the assembly line

Figure 5. Receiving material. Source: Authors.

The material is received in pallets of KLT boxes (Klein Lagerung und Transport or Conditioning and Transportation of Small Components). In accordance to Figure 5b, $\mathrm{KLT}$ boxes allow for a higher volumetric capacity in the transportation of parts. Bin boxes, on the right side of Figure $5 b$, present lower volumetric capacity than KLT boxes, and both are used to restock the assembly line.

The starting point to carry out this work was the full compliance with the demands of the assembly line which must always be taken in consideration in the standardized work of the activities. In case the demands are revised, shifts in the activities among operators are necessary. In the case in point, the client (the assembly line) has two specific needs: payment routes in defined hours and the supply of boxes according to the needs of the assembly line.

Through the bibliographical research in books, theses, and scientific papers, tools to be used in this work were defined: Value Stream Mapping, Operator Balance Chart, and Work Standards Sheet.

In this manner, the work was divided in six stages among which the following can be highlighted: data collection of activities performed by each operator, VSM, Takt Time calculus, the balancing of activities and the implementation of a standard work routine for each operator.

\section{$1^{\text {st }}$ Stage: Design of the current status}

In order to carry out the VSM, the mapping of activities performed by operators was held. These activities are necessary to guarantee the supply of the assembly line. The mapping was represented as a flowchart, observing the order in which activities were performed by operators, aiming to guarantee that the process of payment of the parts is performed according to the clients' necessities. 


\section{$2^{\text {nd }}$ Stage: Data Collection}

As all activities are directly linked to storage and restocking of boxes that are returned from the assembly line, this stage aims to determine the average time for each box. To do so, each operator had all their activities timed throughout five days. This procedure allowed to determine the average time per box, destined to receiving, restocking and sending of boxes that return empty from the assembly line. A digital stopwatch of the brand Vollo was used to collect data referring to the time of each operator (three operators) throughout five days.

Data collected throughout five days were organized in a standard table in order to obtain the average time for each box, as Table 1 shows.

Table 1. Model table of collected times.

\begin{tabular}{|c|c|c|c|c|c|c|c|}
\hline Day & Quantity & Time & Mean & Day & Quantity & Time & Mean \\
\hline Activity $X$ & & & & Activi & & & \\
\hline 1 & 133 & 126.50 & 0.951 & 1 & 103 & 215.92 & 2.096 \\
\hline 2 & 97 & 92.98 & 0.959 & 2 & 83 & 168.48 & 2.030 \\
\hline 3 & 199 & 189.05 & 0.950 & 3 & 104 & 215.53 & 2.072 \\
\hline 4 & 177 & 165.20 & 0.933 & 4 & 66 & 141.15 & 2.139 \\
\hline 5 & 254 & 240.28 & 0.946 & 5 & 94 & 198.15 & 2.108 \\
\hline
\end{tabular}

Source: Authors.

Column 'day' refers to the weekday in which data were collected, with 1 referring to Monday and 5 to Friday. Column 'quantity' refers to the number of boxes that must be restocked and sent again to the assembly line. Time is presented in minutes and it refers to the necessary timing for an activity to be concluded. Arithmetical mean is the ratio of time and the quantity of boxes (minutes per box).

\section{$3^{\text {rd }}$ Stage: Definition of Takt Time}

In this stage, Takt Time was defined using the Equation 1. The quantity of machines manufactured per day in the assembly line (three machines) and the time available per shift (150 minutes) was considered for the calculus.

\section{$4^{\text {th }}$ Stage: Preparation of the Operator Balance Chart}

To distribute activities among operators in a balanced way, the Operator Balance Chart was prepared in an electronic spreadsheet. Its development was carried out with data obtained on the second stage. In this kind of chart, Takt time, calculated in the third stage, is also used; it indicates the limit-time necessary to finish activities.

\section{$5^{\text {th }}$ Stage: Design of the future status}

After observing and analyzing the current status, it is possible to eliminate activities that do not add value to the product or eliminate idleness in the process that may occur throughout the performed activities. The future status is represented by a flowchart. 


\section{$6^{\text {th }}$ Stage: Developing the Work Standards Sheet per operator}

The last stage consisted in creating a Work Standards Sheet for each operator based on the distribution of activities approached in the $4^{\text {th }}$ stage. This stage aims to eliminate the waste in waiting time in order to create a standard work routine, focusing always on the specific restocking of the assembly line.

\section{Results and discussion}

In the first stage of the work, mapping of the activities performed by the employees was carried out. These activities consist on receiving and storing material, separating and stocking empty boxes, and developing payment routes in the assembly line, as it is illustrated by Figure 6 .

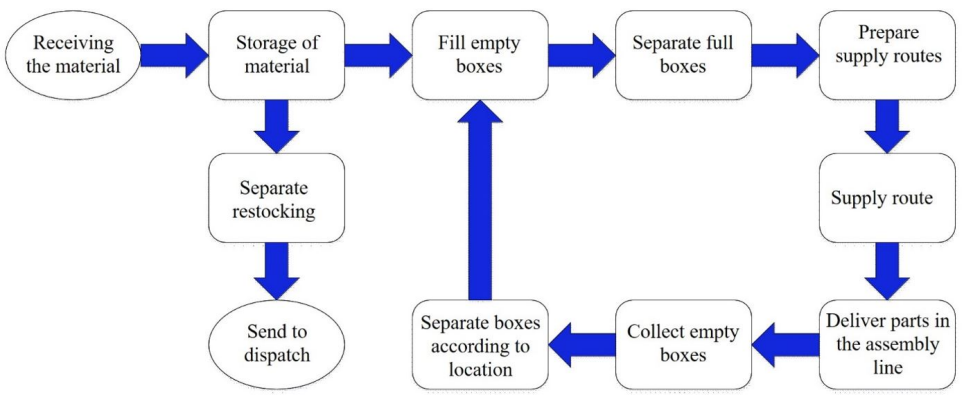

Figure 6. Current Value Stream Mapping. Source: Authors.

Throughout one week (five working days), data were collected referring to the timing of each activity developed in order to guarantee the supply of the production line. In the data collection, day 1 refers to Monday and day 5 to Friday, as it can be seen in Table 2 .

Table 2. Times collected during five days.

\begin{tabular}{|c|c|c|c|c|c|c|c|c|c|c|c|c|c|c|c|}
\hline ๙ิ & 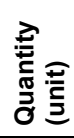 & 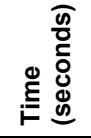 & 离站 & ๙ิ & 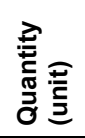 & 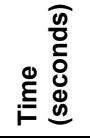 & 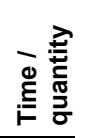 & ฉิ & 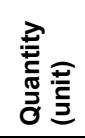 & 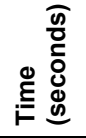 & 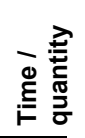 & ลิ & 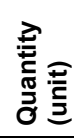 & 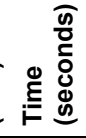 & 站 \\
\hline \multicolumn{4}{|c|}{ Bin A boxes } & \multicolumn{4}{|c|}{ Bin B boxes } & \multicolumn{4}{|c|}{ KLT A boxes } & \multicolumn{4}{|c|}{ KLT B boxes } \\
\hline 1 & 133 & 7590 & 57.1 & 1 & 93 & 12955 & 139.3 & 1 & 39 & 2779 & 71.3 & 1 & 50 & 3353 & 67.1 \\
\hline 2 & 97 & 5579 & 57.5 & 2 & 105 & 10109 & 96.3 & 2 & 76 & 5654 & 74.4 & 2 & 62 & 3918 & 63.2 \\
\hline 3 & 199 & 11343 & 57.0 & 3 & 94 & 12932 & 137.6 & 3 & 63 & 4406 & 69.9 & 3 & 58 & 4014 & 69.2 \\
\hline 4 & 177 & 9912 & 56.0 & 4 & 72 & 8469 & 117.6 & 4 & 21 & 1443 & 68.7 & 4 & 44 & 3276 & 74.5 \\
\hline 5 & 254 & 14417 & 56.8 & 5 & 83 & 11889 & 143.2 & 5 & 71 & 5024 & 70.8 & 5 & 65 & 4418 & 68.0 \\
\hline \multicolumn{4}{|c|}{ Receiving } & \multicolumn{4}{|c|}{ Restocking } & \multicolumn{4}{|c|}{ Supply route } & & & & \\
\hline 1 & 300 & 9360 & 31.2 & 1 & 29 & 2538 & 87.5 & 1 & 3 & 15354 & 5118 & & & & \\
\hline 2 & 282 & 11208 & 39.7 & 2 & 22 & 1516 & 68.9 & 2 & 3 & 13104 & 4368 & & & & \\
\hline 3 & 252 & 12480 & 49.5 & 3 & 27 & 2164 & 80.2 & 3 & 3 & 14868 & 4956 & & & & \\
\hline 4 & 180 & 7032 & 39.1 & 4 & 30 & 2100 & 70.0 & 4 & 3 & 13554 & 4518 & & & & \\
\hline 5 & 228 & 9028 & 39.6 & 5 & 33 & 2086 & 63.2 & 5 & 3 & 12726 & 4242 & & & & \\
\hline
\end{tabular}

Source: Authors. 
For the data collection, each operator developed their activities according to their daily work routine. That allowed for the identification of the time that it took the operator to finish up their activities. At the end of each day, the amount of work performed in a determinate period of each activity performed was obtained. As it is shown in Table 2, the amount of work presented constant oscillations among the number of boxes for each week day. Therefore, the week average was used as a standard time for each activity.

When finishing the work shift and the data collection of the week, it was possible to calculate the arithmetical means of the weekly time for each activity, as it is approached in Table 3.

Table 3. Mean of collected times.

\begin{tabular}{lcccc} 
Activities & $\begin{array}{c}\text { Daily quantity } \\
\text { (units) }\end{array}$ & $\begin{array}{c}\text { Average time } \\
\text { (minutes) }\end{array}$ & $\begin{array}{c}\text { Time/box } \\
\text { (minutes) }\end{array}$ & $\begin{array}{c}\text { Quantity per } \\
\text { Takt time }\end{array}$ \\
\hline Bin A boxes & 172 & 162.80 & 0.95 & 58 \\
\hline Bin B boxes & 89 & 187.85 & 2.10 & 30 \\
\hline KLT A boxes & 54 & 64.35 & 1.19 & 18 \\
\hline KLT B boxes & 56 & 63.27 & 1.13 & 19 \\
\hline Receiving & 248 & 163.69 & 0.66 & 83 \\
\hline Restocking & 28 & 34.68 & 1.23 & 10 \\
\hline Payment route A & 3 & 232.02 & 77.34 & 1 \\
\hline
\end{tabular}

Source: Authors.

The averages of time related to the supply of four kinds of boxes (Bin A, Bin B, KIt $A, K I t B$ ) correspond to the necessary time to carry out the supply of an empty box and its load in the tow. In the case of reception, average time represents the storage of only one box in its correct place in the market. As for replenishment, average time is linked to the separation of one part and its shipment to dispatch. Time related to routes of payment correspond to the average time that it takes the operator to carry the last box restocked in dispatch until its return to the market of parts, after the supply of parts in the assembly line.

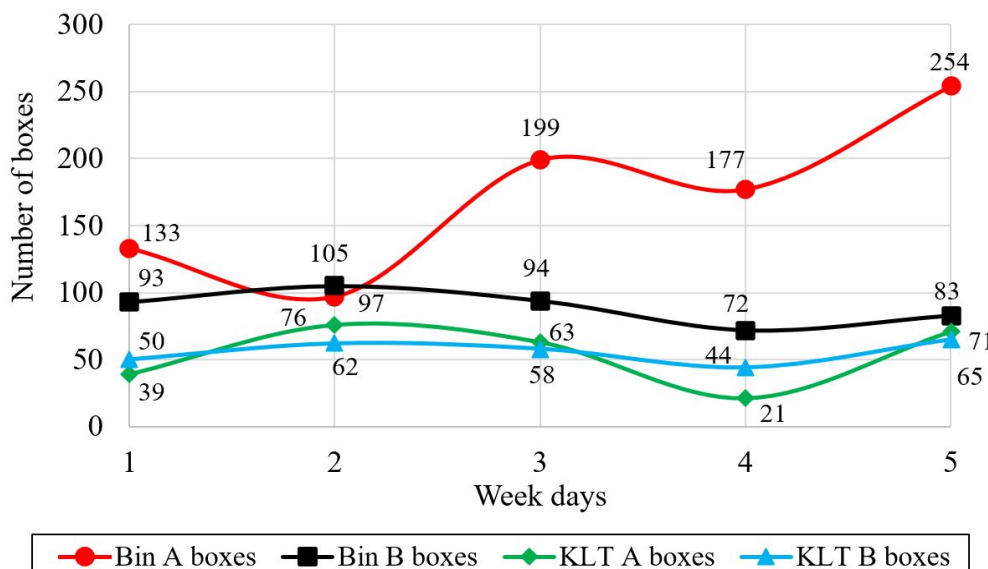

Figure 7- Data collection: boxes that return empty from the assembly line. Source: Authors. 
According to the data presented in Table 2, the number of boxes that returned from the assembly line presented constant variations, even if the number of machines manufactured daily in the assembly line was kept at three machines per day. It is evident by this that the lack of standardized work in this logistics sector affected the pace of the assembly line directly because the boxes were not delivered in the right moment. As it can be seen in Figure 7, there was a variation of 157 Bin A boxes between Tuesday and Friday. The other kinds of boxes also presented considerable variations throughout the week. With this information it was possible to calculate the rate of variation for each type of box throughout five days, with the results of $31,44 \%$ for Bin A boxes and $12,47 \%$ for Bin B boxes. KLT A and KLT B boxes presented a rate of variation of $38,56 \%$ and $16,46 \%$, respectively.

The company defined that a route of payment to each machine leaving the assembly line should be carried out. To calculate Takt Time, where the demand to be met by the assembly line was of three routes per day, it is necessary to know the work time available. The shift begins at 7:30 and ends at 17:30. It allows 1 hour of lunch break and 15 minutes of snack break in the morning shift and other 15 minutes in the afternoon shift. This way, the time available per shift is of 510 minutes. With this information, it is possible to calculate Takt Time, according to the resolution below:

Takt Time $=\frac{510 \text { minutes }}{3 \text { routes }}=170$ minutes $/$ route

Based on the Takt Time concept by Iwayama (1997), routes of payment must occur every 170 minutes, guaranteeing that the payment of parts keeps the pace of the assembly line.

The Operator Balance Chart, illustrated in Figure 8, enabled the division of work load in a similar way among operators, making evident the fact that three people are enough to meet the pace of the assembly line. The sum of activities is below takt time. With this, it is expected that each operator performs their activities in an isolated manner in the production cycle, where each one will perform according the time available for the activities.

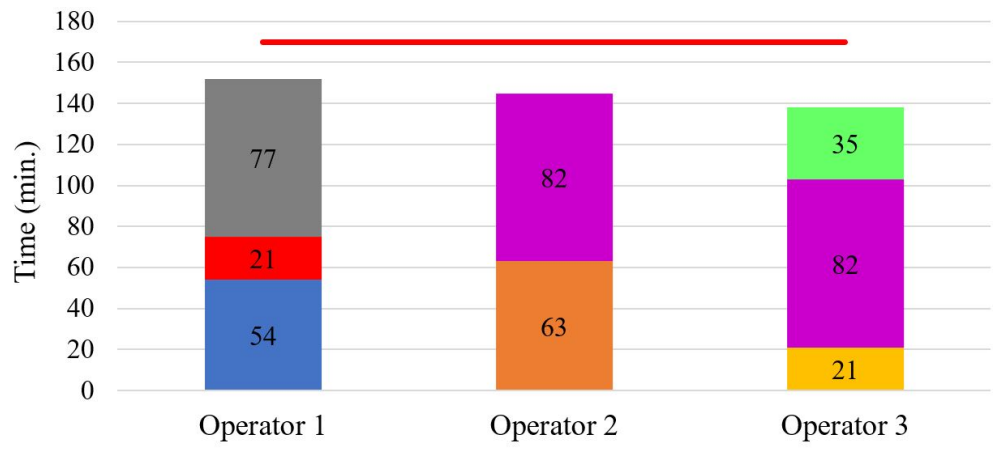

\begin{tabular}{|c|c|c|c|}
\hline Bin A boxes & Bin B boxes & KLT A boxes & KLT B boxes \\
\hline Receiving & Restocking & Supply route & - Takt time \\
\hline
\end{tabular}

Figure 8 - Operator Balance Chart Source: Authors. 
With the current Value Stream Mapping, it was possible to analyze the activities separately, enabling idle activities or reducing idleness of the employees, as it can be seen in Figure 9.

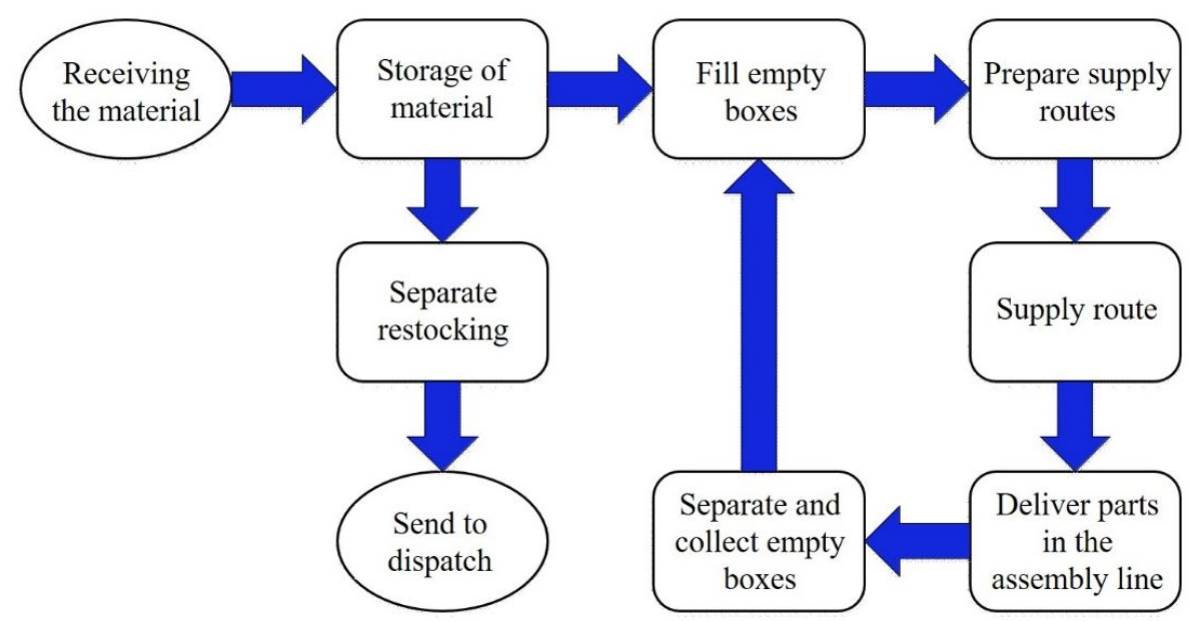

Figure 9. Future Value Stream Mapping. Source: Authors.

As Figure 9 shows, it was possible to eliminate two stages in the process. The stage "separate full boxes" functions as follows: after they are full, boxes are placed below a mezzanine where they are later separated in the dispatch, according to work stations in the assembly line. In the future process, after boxes are replenished, they will be carried directly in the dispatch, avoiding, thus, the transshipment in the mezzanine.

The second stage eliminated, "separate boxes according to the location in the warehouse" will be performed at the moment boxes are taken from the assembly line. In the current process, empty boxes are placed disorderly in the dispatch and separated only after they arrive in the warehouse. This way, in this phase of the work, it was possible to eliminate two activities that did not add value to the production cycle.

The standardized work flow among operators, shown in Figure 10, was implemented based on information from the operator balance chart.

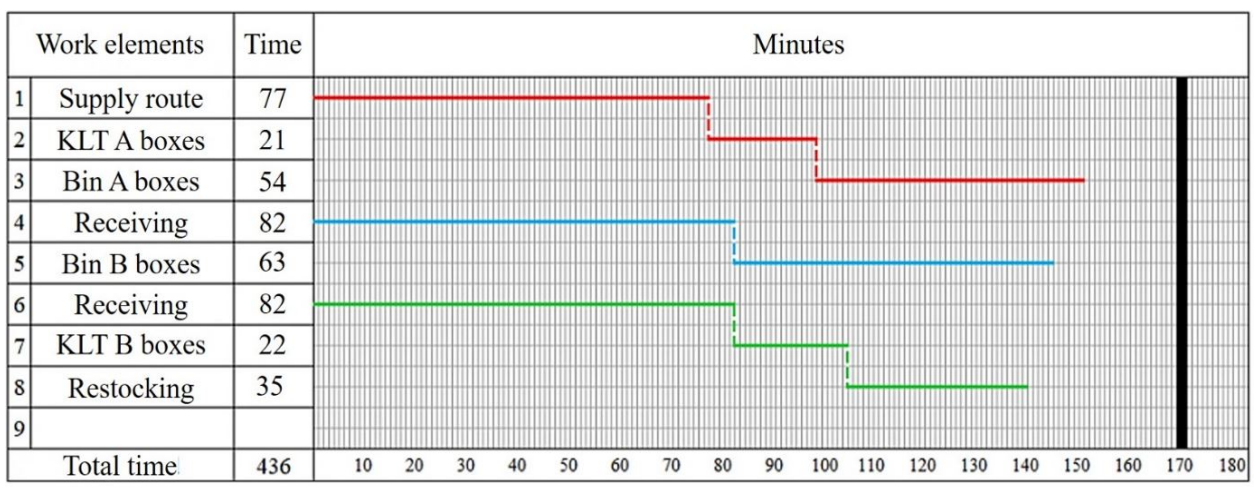

Operator 1: - Operator 2: - Operator 3: - Takt time: I

Figure 10. Work standards sheet among Operators.

Source: Authors. 
The workday begins at 7:30 a.m. when every employee starts their activities, always considering the time for dedication to each operation. Operator 1 will begin their work routine with the route of payment in the assembly line. After finishing their route, they will perform the replenishment of KLT "A", in sequence, replenishment of Bin "A" boxes must be concluded. Operator 2 begins their shift, receiving material and will have as next activity the stocking of Bin "B" boxes. Operator 3 also begins their activities with focus on receiving the material. Later, stocking of KLT B boxes is performed and, finally, the separation of items of replenishment.

It is object of verification that when Operator 1 performs the payment route, other operators are focused in receiving material. Once the route is completed, all boxes that returned from the assembly line are restocked and will return full to the assembly line, in the next payment route. This work routine will be repeated three times daily if there is no change in the demand by the assembly line.

If case of any changes in the client's demand, values in the electronic spreadsheet may be altered at any moment so that a new operator balance chart or a new work standards sheet is organized.

After the definition of tools to be used and which stages would be approached, a one-week training was carried with operators aiming at the use of the tools implemented in this work. In the first day, operators were presented to basic fundamentals of lean manufacturing and how this methodology could enhance the performance of their daily routines by optimizing time and organizing activities. They were also instructed about the tools revised in the literature review and each operator received a work map and specific times in which activities should be performed. At this point, it is important to highlight that the first reaction by operators was of doubt, because they didn't believe the implementation of these tools would be able to optimize time and allow activities to be performed in a more dynamic and organized manner. Throughout the whole of the first week, doubts that came up were properly clarified so that the activity could be performed according to the plan from then on.

After the training period, activities continued to be monitored so that possible improvements of the new work maps could be identified. As it can be observed in Figure 11, the implementation of this work provided a decrease on the oscillation in number of boxes that returned empty form the assembly line, in comparison to Figure 7.

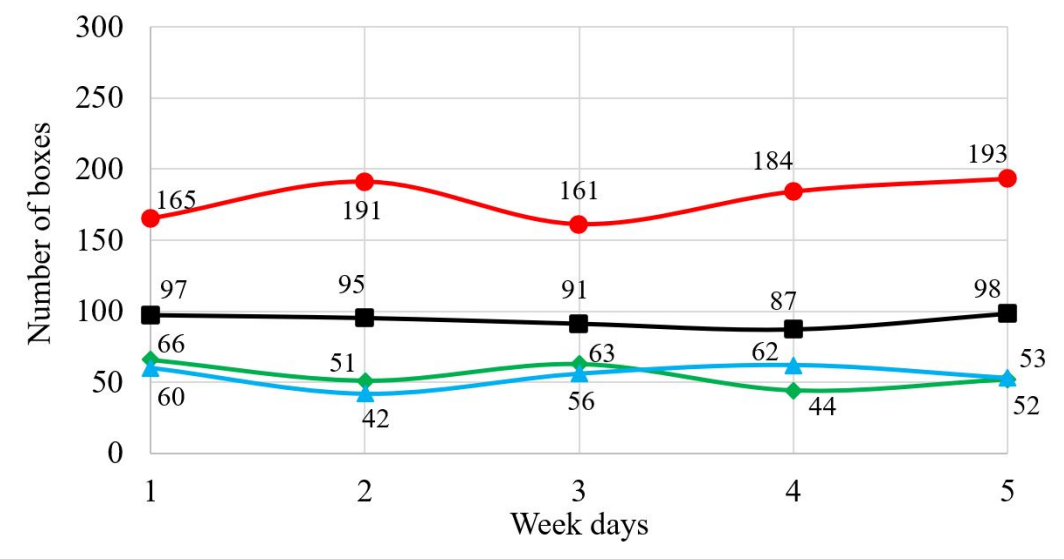

$\multimap-$ Bin A boxes $\rightarrow$-Bin B boxes $\rightarrow$ KLT A boxes $\rightarrow$ KLT B boxes

Figure 11. Week after train and implementation of tools.

Source: Authors. 
This result is confirmed by the decrease of the coefficient of variation among the boxes. Bin $A$ boxes presented a coefficient of variation of $7,4 \%$ while Bin $B$ boxes presented $4,4 \%$. KLT A boxes presented $14,6 \%$ variation and $\mathrm{KLT}$ B presented a coefficient of variation of $12,9 \%$. With this, it was possible to guarantee the demands of the assembly line consistently and in a standard manner, carrying out payment of parts according to the necessary demand, so that the daily assembly of three machines was kept without any delays in sending boxes to the assembly line.

\section{FINAL CONSIDERATIONS}

The implementation of the Lean Manufacturing system made evident the importance of this production system. It can be followed in several sectors of the company as well as in any area of the industry, enabling the continuous enhancement of productions processes.

With the Value Stream Mapping, it was possible to eliminate two operations that did not add value to the product. The sum of time of both eliminated activities was around 8 seconds per box. As the daily average of boxes returned from the assembly line is around 371 boxes, total time gained with the elimination of both activities was of 49,5 minutes per day. Time gained per month corresponds to around 18 hours.

Data collection enabled the definition of average time for each activity, based on boxes that return empty from the assembly line and in the quantity of material received in the warehouse. These quantities may suffer alterations according to the seasonality or because of changes in the clients' necessities. This way, with the information raised in this work, if there is any change in the assembly line, it is enough that values of input for each activity are changed. Instantly, the operator balance chart will show the current status of the process.

To control the pace within which activities should be performed, in order to guarantee full accomplishment in the assembly line, Takt Time and the operator balance chart were important to indicate when routes should be carried out and the definition of which activities each operator must perform.

The work standards sheet provided more harmony among operators throughout the development of their activities. In each operator's activity it is necessary that routes are sent to the assembly line in the right moment and with the right number of stocked boxes, avoiding supply problems.

Before carrying out this work, activities were performed disorderly, without any standard. This generated constant bottlenecks in the area of reception and supply. With this work, it was possible to indicate standards for activities developed and the times of performance for each activity.

According to coefficients of variation calculated, alterations for the number of boxes that returned empty from the line decreased in about $24 \%$ of Bin $A$ boxes while the variation rate in Bin B boxes reduced in $8,07 \%$. For the cases of KLT A and KLT B boxes, their decrease was of $23,96 \%$ and $3,56 \%$, respectively. This way, it is evident that there was a development of standardization and stability in the process as well as enhancement in the continuous flow of materials, and more speed and quality when meeting the needs of the assembly line.

Last, it is important to emphasize that, after the training week, with activities now performed according to the new work procedures, operators were surprised because the supply of the assembly line was organized and without any delays. In the operators' view before the implementation of this work, full supply of the assembly would only be 
possible by contracting another employee. However, this implementation shows that before hiring new staff, processes must be correctly controlled and organized in order to check whether new staff is really necessary.

\section{REFERENCES}

Alvarez, R. R., \& Antunes Jr., J. A. V. (2001). Takt-time: conceitos e contextualização dentro do Sistema Toyota de Produção. Gestão \& Produção, 8(1), 1-18. https://dx.doi.org/10.1590/S0104-530X2001000100002.

Bartz, B., Paula, A., Weise, A. D., \& Ruppenthal, J. E. (2013). Aplicação da manufatura enxuta em uma indústria de equipamentos agrícolas. Ingeniare. Revista Chilena de Ingeniería, 21(1), 147-158. http://dx.doi.org/10.4067/S0718-33052013000100013.

Collatto, D. C., Souza, M. A., Nascimento, A. P., \& Lacerda, D. P. (2016). Interações, convergências e inter-relações entre Contabilidade Enxuta e Gestão Estratégica de Custos: Um estudo no contexto da Produção Enxuta. Gestão \& Produção, 23(4), 815-827. http://dx.doi.org/10.1590/0104-530x1279-15.

Imai, M. (2014). Gemba Kaizen: uma abordagem de bom senso à estratégia de melhoria contínua (2. ed.). Porto Alegre: Bookman.

Iwayama, H. (1997). Basic concept of just in time system, mimeo. Curitiba, PR: IBQP-PR.

Kishida, M., Silva, A., \& Guerra, E. (2006). Benefícios da implantação do trabalho padronizado na Thyssenkrupp. Retrieved in 2018 fevereiro 02, from http://www.lean.org.br/artigos/95/beneficios-da-implementacao-do-trabalho-padronizadona-thyssenkrupp.aspx

Lean Enterprise Institute (2003). Léxico Lean: glossário ilustrado para praticantes do pensamento Lean. São Paulo: Lean Institute Brasil.

Liker, J. K., \& Meier, D. (2007). O modelo Toyota: manual de aplicação. Porto Alegre: Bookman.

Peinado, J., \& Graeml, A. R. (2007). Administração da produção: operações industriais e de serviços. Curitiba: UnicenP.

Rother, M., \& Shook, J. (2003). Aprendendo a enxergar: mapeando o fluxo de valor para agregar valor e eliminar o desperdício. São Paulo: Lean Institute Brasil.

Sabadka, D., Molnar, V., Fedorko, G., \& Jachowicz, T. (2017). Optimization of production processes using the Yamazumi method. Advances in Science and Technology Research Journal, 11(4), 175-182. http://dx.doi.org/10.12913/22998624/80921.

Santos, R. F., \& Alves, J. M. (2015). Proposta de um modelo de gestão integrada da cadeia de suprimentos: aplicação no segmento de eletrodomésticos. Production, 25(1), 125-142. https://dx.doi.org/10.1590/S0103-65132014005000013.

Shingo, S. (1996). O sistema Toyota de produção: Do ponto de vista da engenharia de produção (2. ed.). Porto Alegre: Artes Médicas.

Slack, N., Chambers, S., \& Johnston, R. (2002). Administração da produção (2. ed.). São Paulo: Atlas.

Walter, O. M. F. C., \& Tubino, D. F. (2013). Métodos de avaliação da implantação da manufatura enxuta: uma revisão da literatura e classificação. Gestão \& Produção, 20(1), 23-45. http://dx.doi.org/10.1590/S0104-530X2013000100003.

Wilson, L. (2010). How to implement lean manufacturing. New York: McGraw-Hill.

Womack, J. P.; Jones, D. T.; Roos, D. (1992). A máquina que mudou o mundo (13. ed.). Rio de Janeiro: Campus. 